\title{
ANALISIS EFISIENSI EKONOMI USAHATANI PADI ORGANIK DAN KONVENSIONAL DI KABUPATEN TASIKMALAYA
}

\author{
Nurlela M. ${ }^{\text {) }}$, Nunung Kusnadi' ${ }^{2}$, dan Yusman Syaukat ${ }^{3)}$ \\ ${ }^{1)}$ Program Studi Ilmu Ekonomi Pertanian, Sekolah Pascasarjana, Institut Pertanian Bogor \\ ${ }^{2)}$ Departemen Agribisnis, Fakultas Ekonomi dan Manajemen, Institut Pertanian Bogor \\ ${ }^{3)}$ Departemen Ekonomi Sumberdaya dan Lingkungan, Fakultas Ekonomi dan Manajemen, \\ Institut Pertanian Bogor \\ 1) lelamachmuddin@gmail.com
}

\begin{abstract}
The purpose of this study was to analyze the economic efficiency of organic rice farming compared conventional rice farming. This study conducted using a cross section data from 100 farmers in Tasikmalaya Regency. The farmers are selected using proportionate stratified random sampling technique which is divided into equal size of two levels. Study was performed using stochastic frontier production function and estimated by Maximum Likelihood Estimation (MLE) method. The result showed that the mean economic efficiency of the organic farmers $(0,53)$ is higher compared conventional farmers $(0.43)$. Cost saving of seed and high production in organic farming as a source of gain in economic efficiency. Knowledge on the factors influencing farm efficiency is crucial for policy makers to improving efficiency levels.
\end{abstract}

Keyword(s): efficiency economics, organics vs conventional, rice farming, stochastic-frontier

\begin{abstract}
ABSTRAK
Tujuan penelitian adalah untuk menganalisis efisiensi ekonomi usahatani padi organik dibandingkan dengan usahatani padi konvensional. Penelitian ini menggunakan data Crosssection dengan melakukan wawancara terhadap 100 petani di Kabupaten Tasikmalaya. Pemilihan sampel dilakukan secara stratified random sampling yang terbagi sama besar dalam dua strata. Pengukuran efisiensi dilakukan dengan menggunakan fungsi produksi stochastic frontier yang diestimasi dengan metode Maximum Likelihood Estimation (MLE). Hasil estimasi menunjukkan bahwa rata-rata efisiensi ekonomi usahatani padi organik lebih efisien $(0,53)$ dibandingkan dengan efisiensi ekonomi usahatani padi konvensional $(0,43)$. Biaya bibit yang rendah dan produksi padi yang tinggi pada usahatani padi organik menjadi sumber efisiensi ekonomi. Pengetahuan tentang faktor-faktor yang mempengaruhi efisiensi usahatani sangat penting bagi para pembuat kebijakan untuk meningkatkan efisiensi.
\end{abstract}

Kata Kunci: efisiensi ekonomi, organik vs konvensional, usahatani padi, stochastic-frontier

\section{PENDAHULUAN}

Kajian mengenai efisiensi masih merupakan subyek penelitian di negara berkembang maupun di negara maju. Studi mengenai efisiensi dapat membantu negara-negara berkembang dengan menentukan sejauh mana peningkatan produksi dapat dilakukan melalui peningkatan efisiensi usahatani berdasarkan sumber daya dan teknologi yang 
tersedia (Kibbara, 2005). Efisiensi merupakan indikator dalam mengukur kinerja usahatani (Haryani 2009) dan analisis efisiensi juga merupakan hal utama untuk menaksir keberlanjutan (Madau 2007).

Pertanian organik merupakan salah satu konsep pertanian yang tidak hanya menitikberatkan pada produksi yang tinggi dalam waktu singkat, tapi lebih berorientasi pada peningkatan produksi secara berkesinambungan dan tetap memperhatikan kualitas lahan dan kelestarian lingkungan serta menghasilkan produk yang aman untuk dikonsumsi. Seiring dengan meningkatnya kesadaran akan pentingnya kesehatan mendorong masyarakat untuk mengkonsumsi produk pangan yang aman bagi kesehatan. Salah satunya adalah padi/beras organik yang merupakan komoditas strategis secara sosial-budaya, ekonomi, dan politik. Beras merupakan suatu tanaman pangan yanag dapat memenuhi kebutuhan pangan pokok bagi 95 persen penduduk Indonesia. Pengembangan industri beras di Indonesia dalam jangka panjang selain tetap dikonsentrasikan pada peningkatan produksi beras nasional juga diikuti dengan program perbaikan kualitas beras agar mampu bersaing dengan beras dunia, salah satu upayanya dengan pengembangan beras oganik. Kebutuhan pasar dan produksi padi organik di Indonesia terus meningkat, akan tetapi peningkatan produksi belum mampu mencapai kebutuhan pasar yang dapat diamati pada tahun 2009, produksi padi organik di Indonesia hanya sebesar 57.70 ton, sedangkan kebutuhan pasar sebesar 114.11 ton. Kondisi ini merupakan peluang untuk mengembangkan padi/ beras organik di Indonesia (Asrulhoesein 2010).

Petani padi organik yang dijadikan sebagai demplot dalam hal budidaya padi organik saat ini adalah petani organik di wilayah Kabupaten Tasikmalaya sebab petani organik di Kabupaten Tasikmalaya telah mendapatkan sertifikasi organik dari Sucofindo dan IMO (Institue for Marketecology) dari Swiss (Dinas Pertanian Jawa Barat 2015). Akan tetapi kondisi saat ini bahwa sekitar 5.700 ha padi sawah di wilayah Kabupaten Tasikmalaya hanya sekitar 360 ha diolah secara organik yang ditandai dengan adanya sertifikasi organik. Hal ini menandakan bahwa respon petani terhadap pengembangan padi organik yang mulai dikembangkan sejak tahun 2003, berjalan dengan lambat. Lambatnya respon petani terhadap penerapan budidaya padi organik diduga karena dalam prakteknya petani menghadapi kendala dalam penerapannya (Gultom 2014); (Nurani 2014).

Beberapa penelitian tentang kinerja pertanian organik dibandingkan pertanian konvensional (dalam hal produktivitas, biaya produksi dan hasil finansial) telah dilakukan di negara-negara lain, termasuk Indonesia. Hasil studi di Afrika misalnya mengungkapkan bahwa sistem pertanian organik ternyata mampu meningkatkan produktivitas dan ketahanan pangan, mengurangi ketergantungan terhadap input pertanian dari luar (eksternal), meningkatkan penghasilan petani dan mendorong kelestarian lingkungan (UNCTAD 2009). Akan tetapi, beberapa pendapat juga mengatakan bahwa 
pertanian organik sulit untuk dikembangkan salah satunya karena usahatani padi organik menggunakan input seperti pupuk dan pestisida yang dapat dibuat sendiri oleh petani sehingga biaya bahan baku lebih rendah, tetapi akan memerlukan tenaga kerja yang lebih untuk mempersiapkannya sedangkan pada padi konvensional menggunakan input seperti benih, pupuk dan pestisida kimia yang harus dibeli, tetapi karena tak perlu memproduksi sendiri, pemakaian sarana produksi pertanian kimia ini akan menghemat tenaga kerja (Nugrahaeni 2015). Tantangan lain untuk memasuki usaha pertanian sistem organik adalah dalam hal konversi lahan yang memakan waktu sekitar 2 tahun dan sistem multikultur dan pencegahan hama yang membuat komponen labor cost menjadi tinggi dibandingkan dengan sistem konvensional (Madau 2007). Hal ini menimbulkan pertanyaan apakah sistem organic farming ini mampu bertahan dan secara ekonomis efisien dan dapat bersaing dengan sistem konvensional yang telah berpuluh tahun menjadi tumpuan pemberi makan penduduk dunia? Analisis melalui efisiensi merupakan hal utama untuk menaksir keberlanjutan dan optimalisasi sumberdaya internal petani.

Berdasarkan uraian latar belakang tujuan dari penelitian adalah 1) menganalisis efisiensi teknis usahatani padi organik dibandingkan dengan usahatani padi konvensional; 2) Mengidentifikasi faktor-faktor sosial ekonomi yang menjadi sumber terjadinya inefisiensi teknis; 3) menganalisis tingkat efisiensi alokatif dan ekonomis usahatani padi organik dibandingkan dengan usahatani padi konvensional.

\section{METODE PENELITIAN}

\section{Lokasi dan Waktu Penelitian}

Penelitian ini dilakukan di Kabupaten Tasikmalaya Provinsi Jawa Barat secara sengaja (purposive) dengan pertimbangan bahwa petani organik di Tasikmalaya dijadikan demonstration plot (demplot) dalam pengembangan tanaman padi organik sejak tahun 2014 oleh Kementerian Pertanian dan juga merupakan daerah sentra produksi padi organik yang dijadikan lokasi intervansi oleh Dinas Pertanian dan Tanaman Pangan Kabupaten Tasikmalaya selama lebih dari 2 tahun terakhir, serta telah memperoleh sertifikat sebagai produsen pangan organik dari lembaga sertifikasi pangan organik. Penelitian ini dilaksanakan pada bulan Mei sampai Juli 2015.

\section{Jenis dan Sumber Data}

Penelitian ini menggunakan data cross section tahun 2015. Sumber data yang digunakan dalam penelitian ini adalah data primer dan data sekunder. Data primer yang diambil adalah data karakteristik petani dan usahatani padi sawah pada satu musim tanam, sedangkan data skunder dikumpulkan dari data hasil laporan Pusat Data dan Informasi Pertanian (Pusdatin), Dinas Pertanian Tanaman Pangan dan Hortikultura Kabupaten Tasikmalaya, Data Laporan Tahunan Gapoktan Simpatik. Metode pengambilan sampel dalam penelitian ini dilakukan dengan teknik stratified random sampling yaitu metode pemilihan sampel dengan cara 
membagi populasi ke dalam kelompokkelompok yang homogen yang disebut dengan strata yang kemudian sampel dipilih secara proporsional (proportionate) yang terdiri dari 50 petani organik dan 50 petani konvensional. Petani organik yang dipilih adalah petani yang telah mendapatkan sertifikat sebagai produsen pangan organik dari lembaga sertifikasi organik (Sucofindo dan IMO Swiss).

\section{Metode Analisis Data}

Analisis yang dilakukan dalam penelitian ini meliputi analisis fungsi produksi, analisis efisiensi teknis dan Ekonomi. Pengolahan data dilakukan dengan menggunakan program SPSS 15 dan Frontier 4.1.

Fungsi produksi usahatani dalam penelitian ini menggunakan stochastic frontier production function dengan model yang dikembangkan oleh Bettese dan Coelli (1998). Fungsi produksi frontier stokastik diasumsikan mempunyai bentuk Cobb-Douglas yang ditransformasikan ke dalam bentuk linier logaritma natural sebagai berikut :

1. Model persamaan untuk usahatani padi organik

$$
\begin{aligned}
& \ln Y_{\text {org }}=\beta_{0}+\beta_{L} \ln X_{L}+\beta_{B} \ln X_{B}+ \\
& \beta_{P K} \ln X_{P K}+\beta_{M o l} \ln X_{M o l}+ \\
& \beta_{N a b} \ln X_{N a b}+\beta_{T K L K} \ln X_{T K L K} \\
& + \text { vi- } \\
& \text { ui....... } \\
& Y_{\text {org }}=\text { jumlah total produksi padi organik (kw } \\
& \text { gabah basah panen) } \\
& \mathrm{X}_{\mathrm{L}} \quad \text { = luas lahan (hektar) } \\
& \mathrm{X}_{\mathrm{B}} \quad=\text { benih }(\mathrm{kg}) \\
& \mathrm{X}_{\mathrm{PK}} \quad=\text { pupuk kandang }(\mathrm{kg}) \\
& \mathrm{X}_{\text {Mol }}=\text { Mikro Organisme Lokal (liter) } \\
& \mathrm{X}_{\mathrm{Nab}}=\text { pestisida nabati (liter) } \\
& \mathrm{X}_{\mathrm{TKLK}}=\text { tenaga kerja luar keluarga(HKSP) } \\
& \beta_{0} \quad=\text { intersep }
\end{aligned}
$$

$$
\begin{aligned}
& \beta_{\mathrm{L},} \beta_{\mathrm{B},} \beta_{\mathrm{PK},} \beta_{\mathrm{Mol},} \beta_{\mathrm{Nab},} \beta_{\mathrm{TKLK}}=\text { parameter yang } \\
& \text { diestimasi } \\
& v i-u i \begin{array}{l}
\text { error term (efek inefisiensi di dalam } \\
\text { model) }
\end{array}
\end{aligned}
$$

2. Model persamaan untuk usahatani padi konvensional

$$
\begin{aligned}
\ln Y_{k o n}= & \beta_{0}+\beta_{L} \ln X_{L}+\beta_{B} \ln X_{B}+ \\
& \beta_{P} \ln X_{P}+\beta_{\text {Pest }} \ln X_{\text {Pest }}+ \\
& \beta_{T K} \ln X_{T K}+v i- \\
& \text { ui................................... }
\end{aligned}
$$

$Y_{\text {kon }}=$ jumlah total produksi padi organik (kw gabah basah panen)

$\mathrm{X}_{\mathrm{L}} \quad$ = luas lahan (hektar)

$\mathrm{X}_{\mathrm{B}}=$ benih $(\mathrm{kg})$

$\mathrm{X}_{\mathrm{P}} \quad$ pupuk kimia(kg)

$\mathrm{X}_{\text {Pest }}=$ pestisida kimia (liter)

$\mathrm{X}_{\mathrm{TK}}=$ tenaga kerja (HKSP)

$\beta_{0} \quad=$ intersep

$\beta_{\mathrm{L}}, \beta_{\mathrm{B}}, \beta_{\mathrm{P},} \beta_{\text {Pest, }} \beta_{\mathrm{TK}}=$ parameter yang diestimasi

vi- ui = error term (efek inefisiensi di dalam model)

Tanda parameter yang diharapkan adalah $\beta_{0}, \beta_{\mathrm{L}}, \beta_{B}, \beta_{\mathrm{P}}, \beta_{\text {Pest, }} \beta_{\mathrm{TK}}>0$ atau dengan kata lain diharapkan memberikan nilai parameter dugaan yang bertanda positif.

\section{Analisis Efisiensi}

Model estimasi stochastic frontier dengan menggunakan motode Maximum Likelihood (MLE) dapat diukur dengan menggunakan rumus berikut (Coelli 1998):

$$
\begin{aligned}
& \mathrm{TE}=\frac{y_{i}}{y^{*}}=\frac{y_{i}}{\exp \left(x_{i} \beta\right)}=\frac{\exp \left(x_{i} \beta+V i-U i\right)}{\exp \left(x_{i} \beta+V i\right)} \\
& =\exp \left(-u_{i}\right) \quad \mathrm{i}=1,2,3, \ldots, \mathrm{N} \text {. }
\end{aligned}
$$


dimana $\mathrm{y}_{\mathrm{i}}$ adalah produksi aktual dari pengamatan, dan $\mathrm{y}^{*}$ adalah dugaan produksi frontier yang diperoleh dari produksi frontier stochastic. Efisiensi teknis untuk seorang petani berkisar antara nol dan satu atau nilai $\mathrm{TE}_{\mathrm{i}}$ yaiu $0 \leq$ $\mathrm{TE}_{\mathrm{i}} \leq 1$.

Faktor-faktor yang diduga menjadi sumber inefisiensi teknis (ui) dianalisis dengan menggunakan metode pendugaan efek inefisiensi teknis yang dikembangkan oleh Coelli et al . (1998). Nilai parameter distribusi (ui) efek inefisiensi teknis pada penelitian ini dirumuskan sebagai berikut :

\section{$u_{i}=\delta_{0}+\delta_{i} Z_{i}+\ldots+\delta_{n} Z_{n}$ (4)}

dimana $u_{i}=$ efek inefisiensi teknis; $\delta_{0}=$ konstanta,; $Z_{i}$ adalah faktor-faktor penyebab inefisiensi yang diduga berasal dari umur petani $\left(Z_{\text {age }}\right)$,tingkat pendidikan formal petani $\left(Z_{\text {edu }}\right)$, pengalaman berusahatani padi konvensional $\left(Z_{\text {kon }}\right)$, pengalaman berusahatani padi organik ( $\left.Z_{\text {org }}\right)$, Dummy keanggotaan dalam kelompoktani $\left(Z_{\text {kel }}\right)$, frekuensi pertemuan dengan penyuluh $\left(Z_{\text {peny }}\right)$, persentase tingkat penerapan budidaya padi organik $\left(Z_{\text {sni }}\right)$ sesuai dengan SNI No.01-6729-2013. Tanda parameter yang diharapkan adalah: $\delta_{\text {pen, }}$ $\delta_{\text {kon }}, \delta_{\text {org, }} \delta_{\text {kel, }} \delta_{\text {peny, }} \delta_{\text {tek }}>0$ dan $\delta_{\mathrm{u}}<0$. Variabel pengalaman berusahatani padi organik $\left(Z_{\text {org }}\right)$ dan tingkat penerapan budidaya padi organik $\left(Z_{\text {tek }}\right)$ merupakan variabel yang diduga berpengaruh terhadap inefisiensi teknis usahatani padi organik.
Efisiensi alokatif dan ekonomis dianalisis dari sisi input dengan menggunakan informasi harga input ratarata yang berlaku ditingkat petani. Untuk mengukur efisiensi alokatif, dapat dilakukan dengan menurunkan fungsi biaya dual dari fungsi produksi frontier. Model fungsi biaya dual frontier yang dihasilkan sebagai berikut :

$\ln C^{*}=\underset{\ln }{\beta_{0}}+\beta_{1} \ln Y+\beta_{1} \ln P_{1}+\ldots \ldots . .+\beta_{i}$

dimana $\mathrm{C}^{*}$ adalah biaya produksi padi (Rp), $\quad \mathrm{P}_{\mathrm{i}}$ adalah harga-harga input produksi yaitu harga sewa lahan, harga benih, harga pupuk kandang, harga pupuk, harga pestisida, dan harga upah tenaga kerja baik tenaga kerja dalam keluarga maupun tenaga kerja luar keluarga, sedangkan $\mathrm{Y}$ adalah produksi padi organik/konvensional. Efisiensi ekonomis (EE) sebagai rasio total biaya produksi minimum yang diobservasi ( $\mathrm{C}^{*}$ ) dengan total biaya produksi aktual (C) (Ogundari and Ojo 2008) seperti terlihat pada persamaan berikut :

$\begin{aligned} \mathrm{EE}_{\mathrm{i}} & =\frac{C *}{C}=\frac{E(C i \mid \mu i=0, Y i, P i)}{E(C i \mid \mu i, Y i, P i)} \\ & =\quad \mathrm{E}\end{aligned}$

$\left(U_{i}\right) / \varepsilon_{i}$

].........................(6)

dimana EE bernilai $0 \leq \mathrm{EE} \leq 1$. Efisiensi alokatif (AE) per petani diperoleh dari rasio antara efisiensi ekonomis (EE) dengan efisiensi teknis (ET) .

HASIL DAN PEMBAHASAN 
Perbandingan Penggunaan Input dan Produksi pada Usahatani Padi Organik dan Usahatani Padi Konvensional

Luas lahan yang dikuasai petani di wilayah penelitian tergolong sempit (ratarata kurang dari 0,5 hektar). Rata-rata luas lahan tanaman padi petani padi organik adalah 0,33 hektar sedangkan pada petani konvensional 0,19 hektar (Tabel 1). Luas lahan tidak berpengaruh terhadap penerapan padi baik secara organik maupun secara konvensional. Rata-rata petani padi organik telah mengusahakan lahannya secara organik selama 7,5 tahun.

Penggunaan input benih pada usahatani padi organik rata-rata 9,67 kilogram per hektar lebih sedikit dibandingkan dengan penggunaan benih pada usahatani padi konvensional yang rata-ratanya adalah 42,01 kilogram per hektar. Hal ini disebabkan karena petani padi organik dalam penerapannya juga mengaplikasikan prinsip SRI (System Rice of Intensification) yang salah satunya yaitu penggunaan bibit yang minimum dengan anggapan bahwa apabila benih ditanam banyak, maka benih tersebut akan bersaing satu sama lain dalam penyerapan nutrisi, oksigen, dan sinar matahari. Jumlah bibit per lubang yang digunakan oleh petani dalam budidaya padi organik adalah 2-3 bibit per lubang sedangkan pada budidaya padi konvensional rata-rata jumlah bibit 3-9 bibit per lubang.

Penggunaan pupuk kandang pada usahatani padi organik 4.533,45 per hektar, lebih tinggi dibandingkan pada usahatani padi konvensional (330,98 kg per hektar) Hal ini disebabkan karena pada budidaya padi konvensional terdapat juga pemberian pupuk anorganik, berupa urea, posca, dan SP-36 yang memiliki komposisi kandungan unsur hara per satuannya lebih tinggi dibandingkan pada pupuk kandang/organik. Nurrani (2014) mengemukakan bahwa ada umumya nilai pupuk yang terkandung pada pupuk organik terutama unsur makro nitrogen $(\mathrm{N})$; fosfor $(\mathrm{P})$; dan kalium (K) adalah rendah, oleh karena itu kebutuhan pupuk organik haruslah dalam jumlah yang banyak. 
Selain pupuk kandang, jenis pupuk lain yang digunakan dalam usahatani padi organik yaitu Mikro Organisme Lokal (MOL) yang merupakan pupuk organik cair buatan petani sendiri yang berasal dari berbagai macam larutan bahan-bahan nabati atau hijauan seperti daun pincung, keong, sampah dapur, air cucian beras, buah-buahan seperti mengkudu, pisang, pepaya, pucuk labu, ataupun rebung pisang, dan bahan nabati lainnya. Ratarata penggunaan MOL per hektar lahan oleh petani padi organik adalah 30,09 liter.Usahatani padi organik juga menggunakan pestisida nabati yang dibuat sendiri oleh petani dengan memanfaatkan bahan-bahan nabati yang ada di sekitar petani seperti daun nimba, bawang putih, buah maja, atau buah- usahatani padi konvensional adalah sama. Penggunaan tenaga kerja pada usahatani organik rata-ratanya adalah 223,96 HKSP per hektar, lebih tinggi dibandingkan pada usahatani padi konvensional dengan pada usahatani padi konvensional dengan rata-rata penggunaan tenaga kerjanya adalah 152,75 HKSP. Tingginya penggunaan tenaga kerja pada usahatani padi organik disebabkan karena usahatani padi organik lebih intensif menggunakan tenaga kerja (lobor intensive) khususnya dalam kegiatan penyiangan, pemupukan, dan penyemprotan. Petani organik selalu intensif melakukan penyiangan, biasanya 4 sampai 6 kali sampai panen sebab lahan petani dibiarkan dalam kondisi macakmacak dan juga lahan petani memiliki kandungan humus sehingga gulma pun

Tabel 1. Perbandingan Rata-Rata per Hektar Penggunaan Input dan Produksi Padi pada Usahatani Padi Organik dan Usahatani Padi Konvensional

\begin{tabular}{|c|c|c|c|c|c|}
\hline \multirow[t]{2}{*}{ Peubah } & \multirow[t]{2}{*}{ Satuan } & \multicolumn{2}{|c|}{$\begin{array}{c}\text { Usahatani padi } \\
\text { organik }\end{array}$} & \multicolumn{2}{|c|}{$\begin{array}{l}\text { Usahatani padi } \\
\text { Konvensional }\end{array}$} \\
\hline & & Rata-Rata & St.Dev & Rata-Rata & St.Dev \\
\hline Luas Lahan & $\mathrm{Ha}$ & 0,33 & 0,30 & 0,19 & 0,24 \\
\hline Benih & $\mathrm{Kg}$ & 9,67 & 2,69 & 42,01 & 8,93 \\
\hline Pupuk Kandang & $\mathrm{Kg}$ & $4.533,45$ & $1.416,56$ & 330,98 & 24,04 \\
\hline MOL & Liter & 30,09 & 8,12 & - & \\
\hline Pupuk Urea & $\mathrm{Kg}$ & - & & 250,53 & 57,89 \\
\hline Pupuk Posca & $\mathrm{Kg}$ & - & & 68,24 & 18,94 \\
\hline Pupuk SP-36 & $\mathrm{Kg}$ & - & & 17,8 & 7,00 \\
\hline Pestisida Nabati & Liter & 11,82 & 2,87 & - & \\
\hline Pestisida Kimia & Liter & - & & 75,19 & 11,00 \\
\hline Tenaga Kerja & HKSP & 223,96 & 61,76 & 152,75 & 24,18 \\
\hline Produksi & $\mathrm{Kg}$ & 6.054 & 1.883 & 4.670 & 1.128 \\
\hline
\end{tabular}

buahan yang telah membusuk. Perbandingan rata-rata per hektar penggunaan input dan produksi padi pada usahatani padi organik dan usahatani padi konvensinal disajikan pada Tabel 1.

Kegiatan-kegiatan yang terdapat dalam usahatani padi organik dan tumbuh subur. Sedangkan petani konvensional umumnya cukup melakukan 2 kali penyiangan sebab gulma tumbuh relatif lebih sedikit karena lahan sawah konvensional digenangi air.

Produksi per hekter atau produktivitas lahan usahatani padi organik rata- 
ratanya 6.054 kilogram, lebih tinggi dibandingkan produksi padi per hektar pada usahatani konvensional yaitu dengan rata-rata 4.670 kilogram (Tabel 1). Tingginya produksi padi pada usahatani padi organik diduga karena petani padi organik menggunakan benih padi benih unggul dan melakukan uji benih sebelum persemaian sehingga risiko tanaman padi terserang hama dan penyakit relatif kecil dibandingkan pada usahatani padi konvensional. Selain itu, kegiatan dalam pemeliharaan padi juga lebih intensif pada usahatani padi organik, rata-rata lahan sawah petani telah melewati masa konversi karena telah diolah secara organik selama 7,5 tahun sehingga keunggulan yang dimiliki oleh pupuk organik telah ada pada lahan petani atau dengan kata lain, tingkat kesuburan lahan petani semakin meningkat. Hasil ini sama dengan hasil penelitian yang dilakukan oleh Nurani (2014); Yasin (2014) Tien (2010) bahwa produktivitas usahatani padi yang menerapkan pertanian organik lebih tinggi dari produktivitas usahatani yang menerapkan pertanian konvensional. Aplikasi pertanian organik dengan segala komponen teknologinya akan meningkatkan kesuburan tanah sehingga terjadi peningkatan produktivitas.

Meskipun demikian, dilihat dari nilai standar deviasinya, produksi pada usahatani padi oganik lebih bervariasi dibandingkan usahatani padi konvensional sehingga peluang untuk memperoleh produksi yang rendah juga lebih besar pada usahatani padi organik yang diduga disebabkan oleh variasi aplikasi usahatani organik berbeda antar petani.
Variasi yang tinggi pada usahatani padi organik menunjukkan bahwa aplikasi teknologi penerapan padi secara organik lebih beragam antar petani organik dibandingkan secara konvensional. Besaran variasi ini juga dapat diartikan bahwa risiko usahatani padi organik lebih tinggi dibandingkan usahatani konvensional. 
Terdapat perbedaan penggunaan input yang diduga berpengaruh terhadap produksi pada usahatani padi organik dan konvensional. Pada usahatani padi
Hasil pendugaan stochastic frontier pada Tabel 2 menggambarkan kinerja terbaik (best practice) dari petani padi organik maupun petani padi konvensional

Tabel 2. Hasil Estimasi Fungsi Produksi Stochastic Frontier dengan Metode Maximum Likeyhood (MLE)

\begin{tabular}{|c|c|c|c|c|}
\hline \multirow[t]{2}{*}{ Jenis Input } & \multicolumn{2}{|c|}{ Usahatani padi organik } & \multicolumn{2}{|c|}{$\begin{array}{l}\text { Usahatani Padi } \\
\text { Konvensional }\end{array}$} \\
\hline & Koefisien & t-ratio & Koefisien & t-ratio \\
\hline Konstanta & 2,48 & 16,01 & 2,31 & 16,31 \\
\hline Lahan $\left(\operatorname{LnX}_{1}\right)$ & 0,77 & $23,45^{*}$ & 0,73 & $8,06^{*}$ \\
\hline Benih $\left(\operatorname{LnX} X_{2}\right)$ & 0,04 & $1,48^{* * *}$ & 0,23 & $5,96 *$ \\
\hline Pupuk ( $\left.\operatorname{LnX}_{3}\right)$ & $0,09^{\odot \mathrm{kan}}$ & $2,12 * *$ & $0,03^{\circledR a n}$ & 0,58 \\
\hline $\operatorname{Mol}\left(\operatorname{LnX}_{4}\right)$ & 0,05 & $2,17 * *$ & - & - \\
\hline Pestisida $\left(\operatorname{LnX}_{5}\right)$ & $0,05^{\odot \text { pes }}$ & $2,82^{*}$ & $0,00^{\circledR \mathrm{kim}}$ & 0,19 \\
\hline Tenaga Kerja $\left(\operatorname{LnX} X_{6}\right)$ & $0,05^{\odot \mathrm{TKLK}}$ & $2,02 * *$ & $0,14^{\circledR \mathrm{TK}}$ & $1,58 * * *$ \\
\hline Sigma-square $\left(\sigma^{2}\right)$ & & 0,003 & & 0,059 \\
\hline $\operatorname{Gamma}(\gamma)$ & & 0,999 & & 0,936 \\
\hline L-R test & & 20,868 & & 28,410 \\
\hline CTRS & & 1,054 & & 1,090 \\
\hline
\end{tabular}

Keterangan :

signifikan pada taraf $\alpha *=1 \% ; * *=5 \% ; * * *=10 \%$

Ckan : pupuk kandang @ @an : pupuk anorganik

(Opes : pestisida nabati

(Bkim : pestisida kimia (anorganik)

OTKLK : tenaga kerja luar keluarga

(TK : tenaga kerja (keluarga+luar Kel.)

organik, inputnya terdiri dari yaitu luas lahan, benih, pupuk kandang, pupuk MOL (Mikro Organisme Lokal), pestisida nabati, dan tenaga kerja. Sedangkan pada usahatani konvensional input yang diduga berpengaruh terhadap produksi padi yaitu luas lahan, benih, pupuk yang terdiri dari pupuk kandang, urea, SP-36, dan Phosca, pestisida kimia jenis Decis dan Furadan, serta tenaga kerja, baik yang berasal dari dalam keluarga maupun yang berasal dari luar keluarga.

\section{Analisis Fungsi Produksi}

pada tingkat teknologi yang ada. Baik pada model usahatani padi organik, maupun pada model usahatani konvensional masing-masing memiliki nilai $\log$ likelihood dengan metode MLE lebih besar dari nilai log likelihood dengan metode OLS. Hal ini berarti bahwa fungsi produksi fungsi produksi dengan metode MLE adalah baik sesuai dengan kondisi di lapangan.

Nilai gamma $(\gamma)$ dalam model secara statistik $>0(\gamma=0,999$ dan 0,936$)$. Hal ini menunjukkan variasi produksi usahatani padi organik dan konvensional terjadi bukan karena faktor kebetulan, tapi aktual terutama karena faktor inefisiensi teknis. 
Jadi terbukti bahwa fungsi produksi Cobb-Douglas mampu dengan baik menjelaskan data yang ada tentang terjadinya fenomena inefisiensi teknis pada usahatani tersebut.

Nilai varians $\left(\sigma^{2}\right)$ pada usahatani padi organik dan konvensional masingmasing adalah $\sigma^{2}=0,003$ dan 0,059 secara statistik signifikan pada $\alpha=1$ persen. Hal ini menunjukkan bahwa variasi produksi yang disumbangkan oleh inefisiensi teknis pada usahatani padi organik adalah 0,3 persen, sedangkan pada usahatani padi konvensional sebesar 5,9 persen.

Koefisien dalam fungsi produksi yang merupakan pangkat dari fungsi Cobb-Douglas adalah elastisitas produksi masing-masing input yang digunakan. Jumlah koefisien fungsi ini merupakan kondisi return to scale. Jumlah koefisien masing-masing input dalam fungsi produksi menghasilkan angka 1,054 pada usahatani organik dan 1,090 pada usahatani padi konvensional. Masingmasing jumlah koefisien yang dipoleh mendekati satu sehingga dapat disimpulkan bahwa skala usaha petani padi organik dan petani padi konvensional di daerah penelitian berada pada kondisi Constant Return to Scale.

Pada usahatani padi organik, input luas lahan $\left(\mathrm{LnX}_{1}\right)$, benih $\left(\mathrm{LnX}_{2}\right)$, pupuk kandang $\left(\operatorname{LnX}_{3}{ }^{\odot \mathrm{kan}}\right)$, Mol $\left(\operatorname{LnX}_{4}\right)$, pestisida nabati $\left(\mathrm{LnX}_{5}{ }^{\text {Opes }}\right)$ dan tenaga kerja dalam hal ini tenaga luar keluarga $\left(\mathrm{LnX}_{6}{ }^{\text {๑TKLK }}\right.$ ) mempunyai koefisien yang positif dan responsif terhadap produksi. Sedangkan pada usahatani padi konvensional, input yang berpengaruh positif dan responsif terhadap produksi yaitu luas lahan $\left(\operatorname{LnX} X_{1}\right)$, benih $\left(\operatorname{LnX} X_{2}\right)$, dan tenaga kerja baik dalam maupun luar keluarga $\left(\mathrm{LnX}_{6}{ }^{\odot \mathrm{TK}}\right)$. Sedangkan input pupuk kimia $\left(\operatorname{LnX}_{3}{ }^{\circledR k i m}\right)$ dan pestisida kimia $\left(\mathrm{LnX}_{5}{ }^{\circledR \mathrm{kim}}\right)$ bertanda positif tapi tidak responsif terhadap produksi. Hal ini mengindikasikan bahwa peningkatan jumlah penggunaan pupuk anorganik (Urea, SP-36, dan phosca) dan pestisida kimia pada usahatani padi konvensional, tidak responsif lagi terhadap peningkatan produksi padi.

\section{Analisis Efisiensi Teknis}

Hasil analisis efisiensi teknis menggunakan model fungsi produksi frontier menunjukkan bahwa secara umum ratarata tingkat efisiensi teknis yang dicapai petani padi pada organik adalah 0.86 (86 persen) sedangkan pada usahatani padi konvensional 0,89 (89 persen) yang berarti bahwa kedua sistem usahatani telah efisien secara teknis. Mengacu pada pendapat Coelli et.al (1998) bahwa suatu usahatani dikatakan telah efisien jika efisiensinya lebih besar atau sama dengan 0,7. Tingkat efisiensi teknis rata-rata Jika dilihat dari persentase pencapaian tingkat efisiensi tertinggi (interval efisiensi 0,91$1,00)$, pencapaian efisiensi tertinggi lebih besar pada petani padi konvensional (68 persen) sedangkan petani padi organik (28 persen) sehingga dapat disimpulkan bahwa petani pada usahatani padi konvensional lebih efisien secara teknis dibandingkan petani pada usahatani padi organik. Hasil penelitian ini sejalan dengan hasil penelitian Nurani (2014); Yasin (2014); Tiedemann and Uwe (2012) mengenai efisiensi teknik usahatani organik dan konvensional yang 
menyimpulkan bahwa efisiensi teknik usahatani di lahan konvensional lebih tinggi usahatani pada lahan organik. Hal ini berarti bahwa petani padi konvensional di daerah penelitian telah mengalokasikan penggunaan inputnya secara proporsional dan pencapai prestasi keterampilan manajerial yang cukup tinggi. Sedangkan perilaku petani organik dalam menggunakan input masih bervariasi terlihat dari penggunaan benih, pupuk, atau pestisida nabati. Dalam penggunaan benih, petani padi organik menanam bibit satu sampai tiga bibit dalam satu lubang tanam sehingga penggunaan benihnya lebih sedikit, ada pula yang masih menanam benih dalam jumlah biasanya seperti pada usahatani konvensional. Pemberian pupuk organik maupun pestisida nabati yang dibuat sendiri oleh petani mempunyai komposisi dan kandungan unsur hara yang berbedabeda serta frekuensi pemberian yang berbeda-beda pula sehingga berpengaruh terhadap tingkat efisiensi teknis yang dicapai. Sebaran tingkat efisiensi teknis petani padi organik dan konvensional dapat dilihat pada Tabel 3.

Selain merefleksikan prestasi yang dicapai oleh petani, tingkat efisiensi yang tinggi juga merefleksikan bahwa peluang untuk meningkatkan produktivitas yang cukup tinggi semakin kecil karena senjang antara tingkat produktivitas yang telah dicapainya dengan tingkat produksi maksimum yang dapat dicapai dengan sistem pengelolaan terbaik (the best practiced) cukup sempit (Sumaryanto 2003). Dengan tingkat produksi rata-rata per hektar yang dicapai sata ini, maka Peluang untuk meningkatkan produksi maksimum tanpa merubah teknologinya pada usahatani padi organik sebesar 13,13 persen [1-(0,86/0,99)] lebih tinggi dibandingkan pada usahatani padi konvensional yakni sebesar 8,25 persen $[1(0,89 / 0,97)]$. Hal ini berarti bahwa masih ada potensi atau peluang sebesar 13,13 persen pada usahatani padi organik untuk meningkatkan produksi tanpa

Tabel 3. Sebaran Efisiensi Teknis pada Petani Padi Organik dan Konvensional

\begin{tabular}{lcccc}
\hline \multirow{2}{*}{$\begin{array}{c}\text { Tingkat Efisiensi } \\
\text { Teknis }\end{array}$} & \multicolumn{2}{c}{ Usahatani Padi Organik } & \multicolumn{2}{c}{ Usahatani Padi Konvensional } \\
\cline { 2 - 5 } & $\begin{array}{c}\text { Jumlah } \\
\text { Petani }\end{array}$ & Persentase & $\begin{array}{c}\text { Jumlah } \\
\text { Petani }\end{array}$ & Persentase \\
\cline { 2 - 5 } (orang) & $\mathbf{( \% )}$ & (orang) & $\mathbf{( \% )}$ \\
\hline$<0,30$ & 0 & 0 & 0 & 0 \\
$0,31-0,40$ & 0 & 0 & 0 & 0 \\
$0,41-0,50$ & 0 & 0 & 1 & 2 \\
$0,51-0,60$ & 0 & 0 & 0 & 0 \\
$0,61-0,70$ & 0 & 0 & 2 & 4 \\
$0,71-0,80$ & 9 & 18 & 7 & 14 \\
$0,81-0,90$ & 27 & 54 & 6 & 12 \\
$0,91-1,00$ & 14 & 28 & 34 & 68 \\
\hline Jumlah & 50 & 100 & 50 & \\
\hline Maksimum & 0,99 & & 0,97 & \\
Minimum & 0,71 & & 0,47 & \\
Rata-rata & 0,86 & & 0,89 & \\
\hline
\end{tabular}


merubah teknologinya dimana rata-rata produksi saat ini adalah 60,54 ku per hektar. Sedangkan peluang untuk meningkatkan produksi padi konvensional hanya sebesar 8,25 persen dimana rata-rata produksi sata ini adalah 46,70 ku per hektar. Faktor sosial ekonomi yang diduga menjadi sumber penyebab inefisiensi teknis dapat dilihat pada bagian selanjutnya.

\section{Sumber-sumber Inefisiensi Teknis usahatani Padi Organik dan Konvensional}

Secara keseluruhan variabel yang diduga mempengaruhi inefisiensi teknis pada usahatani organik dan konvensional mempunyai tanda sesuai yang diharapkan kecuali pada variabel tingkat penerapan pertanian organik $Z_{\text {tek }}$ sesuai dengan SNI No.01-6729-2013. Variabel $Z_{\text {tek }}$ bertanda positif dan tidak signifikan berpengaruh terhadap inefisiensi. Hal ini diduga karena standar SNI yang dijadikan acuan tidak saja berisi mengenai penjelasan standar dalam penerapan budidaya padi organik (on-farm) tapi juga terhadap standar pada penggunaan alat, perlakuan pasca panen dan lain-lain. Variabel pendidikan (dalam hal ini merupakan lama petani menempuh pendidikan formal) berpengaruh negatif terhadap inefisiensi usahatani padi baik pada usahatani padi organik maupun usahatani padi konvensional. Hal ini berarti bahwa semakin lama tingkat pendidikan formal yang ditempuh petani, maka usahatani padi semakin efisien. Kusnadi et.al (2011) mengemukakan bahwa petani yang berpendidikan tinggi akan lebih terbuka dalam menerima informasi dan perubahan teknologi sehingga dapat meningkatkan atau menurunkan efisiensi. Rata-rata tingkat pendidikan formal yang ditempuh oleh petani padi di daerah penelitian yaitu sampai jenjang tamat SD (6 tahun) yang menunjukkan bahwa ratarata tingkat pendidikan petani masih rendah. Petani dapat meningkatkan pengetahuannya melalui pendidikan informal seperti kursus, pelatihan, dan mencari sumber-sumber pengetahuan baru dari berbagai media cetak dan elektronik.

Pengalaman berusahatani baik secara organik maupun secara konvensional negatif terhadap inefisiensi atau meningkatkan efisiensi usahatani padi baik pada usahatani padi organik maupun pada usahatani konvensional. Hal ini karena semakin lama petani membudidayakan padi, maka pengetahuan dan pengalaman tentang teknik membudidayakan tanaman padi semakin baik. Dimana, tidak terdapat perbedaan teknik budidaya antara padi organik dan padi konvensional melainkan yang berbeda adalah penggunaan jenis inputnya. Pada usahatani padi organik, variabel pengalaman dalam mengusahakan lahan secara organik juga berpengaruh negatif dan signifikan terhadap inefisiensi. Semakin lama berusahatani secara organik, maka akan semakin efisien secara teknis seiring dengan semakin membaiknya kesuburan tanah dengan adanya penggunaan pupuk organik. Patani padi organik di lokasi penelitian rata-rata telah berusahatani secara organik selama 7,5 tahun. 
Status keanggotaan petani dalam kelompok tani pada usahatani padi konvensional bertanda negatif dan signifikan terhadap efisiensi yang artinya bahwa petani yang tergabung menjadi anggota dalam kelompok tani lebih efisien dibandingkan dengan petani yang tidak menjadi anggota. Hal ini disebabkan karena petani yang tergabung menjadi anggota kelompoktani akan cepat mendapatkan informasi yang terkait menurunkan inefisiensi usahatani padi konvensional pada taraf $\alpha=5$ persen. Baik pada petani padi organik maupun pada petani padi konvensional, petani padi yang memiliki frekuensi pertemuan dengan penyuluh lebih tinggi akan lebih intensif mendapatkan informasi yang terkait dengan teknologi baru, peningkatan produktivitas tanaman, cara pemupukan berimbang, atau informasi pasar dibandingkan dengan petani tidak pernah

Tabel 4. Hasil Pendugaan Faktor yang Mempengaruhi Inefisiensi Teknis dengan Pendekatan Analisis Stochastic Frontier

\begin{tabular}{|c|c|c|c|c|}
\hline \multirow[t]{2}{*}{ Variabel } & \multicolumn{2}{|c|}{ Usahatani padi organik } & \multicolumn{2}{|c|}{$\begin{array}{c}\text { Usahatani padi } \\
\text { konvensional }\end{array}$} \\
\hline & Koef. & Standar eror & Koef. & Standar eror \\
\hline Konstanta & 2.483 & 0.156 & 2.312 & 0.141 \\
\hline $\operatorname{Umur}\left(\mathrm{Z}_{\mathrm{u}}\right)$ & 0.086 & 0.071 & 0.068 & 0.093 \\
\hline Pendidikan $\left(\mathrm{Z}_{\mathrm{p}}\right)$ & $(0.067)$ & $(0.032)^{* *}$ & $(0.157)$ & $(0.087)^{* *}$ \\
\hline $\begin{array}{l}\text { Pengalaman UT konvensional } \\
\left(\mathrm{Z}_{\mathrm{kon}}\right)\end{array}$ & $(0.054)$ & $(0.029)^{* *}$ & $(0.021)$ & $(0.115)$ \\
\hline Pengalaman UT organik ( $\mathrm{Z}_{\text {org }}$ ) & $(0.105)$ & $(0.062)^{* *}$ & - & - \\
\hline $\begin{array}{l}\text { Dummy keaktifan dalam } \\
\text { kolompok }\left(\mathrm{Z}_{\mathrm{kel}}\right)\end{array}$ & - & - & $(1.509)$ & $(1.115)^{* * *}$ \\
\hline $\begin{array}{l}\text { Frekuensi ikut penyuluhan } \\
\left(\mathrm{Z}_{\mathrm{pen}}\right)\end{array}$ & $(0.049)$ & $(0.048)$ & $(0.243)$ & $(0.148)^{* *}$ \\
\hline $\begin{array}{l}\text { Tingkat penerapan organik } \\
\left(\mathrm{Z}_{\text {tek }}\right)\end{array}$ & 0.087 & 0.072 & - & - \\
\hline $\operatorname{Gamma}(\gamma)$ & 0.999 & & 0.936 & \\
\hline
\end{tabular}

Keterangan : ** signifikan pada taraf $\alpha 5 \%$; *** signifikan pada taraf $\alpha 10 \%$

dengan teknologi baru, informasi harga padi, atau dapat berbagi pengalaman dengan sesama anggota kelompok mengenai pengelolaan padi yang baik. Pada usahatani organik, semua petani padi organik di wilayah penelitian tergabung dalam kelompoktani sehingga yang dijadikan variabel selanjutnya adalah variabel frekuensi mengikuti penyuluhan.

Frekuensi mengikuti penyuluhan pada usahatani padi konvensional bertanda negatif dan signifikan mengikuti penyuluhan. Hasil ini sama dengan hasil penelitian Akinbode et al.(2011); Prayoga (2010); dan Abedullah et.al (2006) bahwa variabel kontak atau intensitas pertemuan dengan penyuluh berpengaruh terhadap penurunan inefisiensi.

\section{Analisis Efisiensi Alokatif dan Ekonomis Usahatani padi Organik dan Konvensional}


Sebaran efisiensi alokatif pada usahatani padi organik dan usahatani padi konvensional (Tabel 5) menunjukkan bahwa usahatani padi organik maupun usahatani padi konvensional belum efisien secara alokatif. Rata-rata nilai efisiensi alokatif pada usahatani padi organik adalah 0,62, sedangkan rata-rata efisiensi alokatif pada usahatani padi konvensional adalah 0,49. Belum efisiennya petani secara alokatif diduga karena petani belum menggunakan kombinasi input dalam proporsi yang optimal yang dapat meminimalkan biaya usahataninya. Akan tetapi jika produksi padi organik yang lebih optimal dibandingkan produksi padi konvensional. Penggunaan biaya yang lebih minimum pada usahatani padi organik di duga kerena petani membuat atau mengadakan inputnya (pupuk organik dan pestisida nabati) sendiri tanpa harus membeli melainkan dibuat sendiri oleh petani dengan memanfaatkan bahanbahan nabati yang ada di sekitar tempat tinggal petani sehingga lebih meminimumkan biaya dibandingkan pada usahatani konvensional, pengadaaan input benih, pupuk kimia dan obat-obatan harus dibeli oleh petani. Peningkatan

Tabel 5. Sebaran Efisiensi Alokatif, dan Ekonomis

\begin{tabular}{|c|c|c|c|c|c|c|c|c|}
\hline \multirow{3}{*}{$\begin{array}{l}\text { Tingkat } \\
\text { efisiensi }\end{array}$} & \multicolumn{4}{|c|}{ Efisiensi Alokatif (EA) } & \multicolumn{4}{|c|}{ Efisiensi Ekonomi (EE) } \\
\hline & \multicolumn{2}{|c|}{ Organik } & \multicolumn{2}{|c|}{ Konvensional } & \multicolumn{2}{|c|}{ Organik } & \multicolumn{2}{|c|}{ Konvensional } \\
\hline & $\begin{array}{c}\text { Jumlah } \\
\text { petani }\end{array}$ & $\%$ & $\begin{array}{c}\text { Jumlah } \\
\text { petani }\end{array}$ & $\%$ & $\begin{array}{c}\text { Jumlah } \\
\text { petani }\end{array}$ & $\%$ & $\begin{array}{l}\text { Jumlah } \\
\text { petani }\end{array}$ & $\%$ \\
\hline$<0,30$ & 0 & 0 & 0 & 0 & 0 & 0 & 0 & 0 \\
\hline $0,31-0,40$ & 1 & 2 & 10 & 20 & 3 & 6 & 16 & 32 \\
\hline $0,41-0,50$ & 9 & 18 & 25 & 50 & 22 & 44 & 31 & 62 \\
\hline $0,51-0,60$ & 16 & 32 & 9 & 18 & 15 & 30 & 3 & 6 \\
\hline $0,61-0,70$ & 11 & 22 & 4 & 8 & 6 & 12 & 0 & 0 \\
\hline $0,71-0,80$ & 9 & 18 & 1 & 0 & 4 & 8 & 0 & 0 \\
\hline $0,81-0,90$ & 4 & 8 & 0 & 2 & 0 & 0 & 0 & 0 \\
\hline $0,91-1,00$ & 0 & 0 & 1 & 2 & 0 & 0 & 0 & 0 \\
\hline Jumlah & 50 & 100 & 50 & 100 & 50 & 100 & 50 & 100 \\
\hline Rata-rata & \multicolumn{2}{|c|}{0,62} & \multicolumn{2}{|c|}{0,49} & \multicolumn{2}{|c|}{0,53} & \multicolumn{2}{|c|}{0,43} \\
\hline Maks. & \multicolumn{2}{|c|}{0,88} & \multicolumn{2}{|c|}{0,97} & \multicolumn{2}{|c|}{0,78} & \multicolumn{2}{|c|}{$\begin{array}{l}0,57 \\
031\end{array}$} \\
\hline Min. & \multicolumn{2}{|c|}{0,44} & \multicolumn{2}{|c|}{0,32} & \multicolumn{2}{|c|}{0,36} & \multicolumn{2}{|c|}{0,31} \\
\hline
\end{tabular}

membandingkan tingkat efisiensi alokatif yang telah dicapai oleh petani, maka efisiensi alokatif petani pada usahatani padi organik lebih tinggi dibandingkan usahatani padi konvensional. Hal ini menunjukkan bahwa petani padi organik lebih menggunakan kombinasi input dalam proporsi yang optimal pada tingkat biaya minimum sehingga keuntungannya menjadi lebih maksimal. Keuntungan yang maksimal pun diperoleh dari efisiensi alokatif yang harus diupayakan pada usahatani padi organik yaitu 29,54 persen [1-(0,62/0,88)], sedangkan pada usahatani padi konvensional sebesar 49,48 persen [1-(0,49/0,97).

Efisiensi ekonomi merupakan efek gabungan dari efisiensi teknis dan efisiensi alokatif sehingga usahatani dapat efisien secara ekonomis jika efisiensi teknis dan efisiensi ekonomis telah tercapai. Pencapaian tingkat 
ekonomis yang lebih tinggi akan dapat meningkatkan pendapatan dan keuntungan petani. Tabel 5 menunjukkan bahwa rata-rata petani padi organik dan konvensional belum efisien secara ekonomi sebab efisiensi alokatif kedua sistem usahatani tersebut belum efisien. Asogwa (2014) mengemukakan bahwa salah satu penyebab efisiensi ekonomi yang bervariasi disebabkan oleh inefisiensi biaya atau alokatif. Salah satu penyebab fenomena efisiensi alokatif yang rendah adalah informasi harga input yang tidak sempurna dan penggunaan harga rata-rata dalam perhitungan.

Jika membandingkan sebaran nilai efisiensi ekonominya, maka usahatani padi organik lebih efisien secara ekonomis (rata-rata $\mathrm{EE}=0,53$ ) dibandingkan usahatani padi konvensional (rata-rata $\mathrm{EE}=0,43$ ). Hal ini menunjukkan bahwa usahatani padi organik lebih memberikan keuntungan yang maksimum dibandingkan usahatani padi konvensional. Penggunaan jumlah benih yang lebih hemat dan juga perolehan produksi padi organik yang lebih tinggi menjadi penyebab perolehan keuntungan yang lebih tinggi pada usahatani padi organik. Efisiensi ekonomis pada usahatani padi organik dapat ditingkatkan lagi melalui upaya yang lebih mudah seperti pemberian intensif harga yang lebih tinggi lagi pada petani padi organik sebagai penghargaan dalam menghasilkan padi organik yang diketahui labor intensive. Di lokasi penelitian, harga padi organik dan padi konvensional tidak jauh berbeda jika dijual ke pedagang pengumpul yaitu berkisar antara Rp.4.200 sampai Rp 4.500 kilogram per kilogram. Sedangkan petani yang menjual ke Gapoktan Simpatik diberi intensif harga yang berkisar antara Rp 4.500 sampai Rp 4.800 per kilogram. Akan tetapi karena keterbatasan modal dan fasilitas untuk membeli dan menampung hasil produksi petani sehingga kadangkala Gapoktan Simpatik tidak menerima atau membeli hasil produksi padi organik para petani. Pada akhirnya petani padi organik menjualnya ke pedagang pengumpul karena mereka juga membutuhkan modal dengan segera. Diperlukan lembaga atau pengembangan lembaga yang dapat memasarkan dan menjamin harga premium yang lebih tinggi terhadap produk padi organik petani. Selain itu, peningkatan efisiensi ekonomi pada usahatani padi organik dapat juga dilakukan dengan minimumkan biaya penggunaan pupuk kandang yang dapat dilakukan petani melalui upaya memproduksi kotoran hewan sendiri (beternak sendiri) yang dapat dilakukan sendiri atau melalui kelompok tani sehingga kotoran hewan yang dihasilkan secara mandiri bisa di manfaatkan untuk pupuk organik. 


\section{SIMPULAN DAN SARAN}

\section{Simpulan}

1. Petani padi konvensional lebih efisien secara teknis (rata-rata 0,89) dibandingkan petani padi organik (rata-rata 0,86 ) sebab perilaku petani organik dalam menggunakan input atau menerapkan teknologi padi organik masih bervariasi. Dengan produktivitas yang lebih tinggi yang diperoleh saat ini, maka petani padi organik masih mempunyai peluang meningkatkan produktivitasnya untuk mencapai produksi maksimum (13 persen) dibandingkan pada petani padi konvensional (8 persen).

2. Faktor sosial ekonomi penyebab sumber efisiensi teknis pada usahatani padi organik yaitu tingkat pendidikan formal petani, pengalaman berusahatani secara konvensional dan secara organik. Sedangkan pada usahatani konvensional, faktor penyebab sumber efisiensi teknis yaitu tingkat pendidikan formal petani, keaktifan petani dalam kelompok tani dan intensitas ikut penyuluhan.

3. Tingkat efisiensi alokatif dan ekonomis petani pada usahatani padi organik masing-masing adalah 0,62 dan 0,53 , lebih tinggi dibandingkan efisiensi alokatif dan ekonomi pada usahatani padi konvensional dengan nilai masing-masing 0,49 dan 0,43. Penggunaan jumlah input benih yang lebih hemat dan juga perolehan produksi padi organik yang lebih tinggi menjadi penyebab perolehan efisiensi alokatif dan ekonomis yang lebih tinggi pada usahatani padi organik.

\section{Saran}

1. Peningkatan efisiensi petani padi di Kabupaten Tasikmalaya sebaiknya difokuskan pada perbaikan faktorfaktor sosial ekonomi seperti pendidikan petani dan penyuluhan, yang dapat dilakukan melalui peningkatan sumberdaya petani yang bukan saja melalui pendidikan formal tapi juga dapat dilakukan melalui pendidikan non formal seperti kursus, dan pengembangan program sekolah lapang. Pemberian penyuluhan yang rutin baik petani padi organik maupun petani pada usahatani konvensional. Khususnya bagi petani padi organik dengan tujuan untuk memotivasi petani agar tetap bertahan dalam mengembangkan usahatani padi organik.

2. Sebaiknya biaya-biaya seperti biaya penggunaan input pupuk kandang diminimalisir petani melalui upaya memproduksi kotoran hewan sendiri untuk dapat meningkatkan efisiensi ekonomi petani.

\section{DAFTAR PUSTAKA}

Abedullah, Bashir Ahmad and Khuda Bakhsh, 2006. Technical efficiency and its determinants in potato production, evidence from Punjab, Pakistan. The Lahore J.Economics $11: 2$ (Winter 2006) pp 1-22.

Akinbode, S.O., Dipeolu A.O., and Ayinde I.2011. An Examination of technical, allocative and economic efficiencies in ofada rice farming in Ogun State Nigeria. African 
J.Agricultural Research . Vol.6 (28),pp 6027-6035.

Asogwa, Joseph, and Simon.2011.Economic Efficiency of Nigerian Small Scale Farmers.J Economics,2(2) : 89-98 (2011).

Asrulhoesein. 2010. Proyeksi Produksi dan Padi Organik di Indonesia. Majalah Media Infokom Semai. Bogor: Lembaga Pertanian Sehat (LPS) Dompet Dhuafa.

Coelli, T., D.S.P. Rao and G.E. Battese. 1998. An introduction to efficiency and productivity analysis. Kluwer Academic Publishers, Boston.

[Deptan] Departemen Pertanian. 2007. Road map pengembangan pertanian borganik 2008-2015. http://pphp.deptan.go.id. Diakses 2012 Juni 26.

[Diperta] Dinas Pertanian Tanaman Pangan Jawa Barat. 2015. Beras organik berwarna warni [internet]. Agustus 2010; http://www.diperta.jabarprov.go.id Diakses 27 Februari 2015.

Gultom L.2014.Analisis efisiensi teknis usahatani padi semi organik di Kecamatan Cigombong Kabupaten Bogor [tesis]. Program Pascasarjana Institut Pertanian Bogor, Bogor.

Kusnadi N, Tinaprilla N, Susilowati, dan Purwoto. 2011. Analisis efisiensi usahatani padi di beberapa sentra produksi padi di Indonesia. JAE,29 (1):25-48.

Nurani L E. 2014. analisis efisiensi teknis padi organik di Kabupaten Bogor [tesis]. Program Pascasarjana Institut Pertanian Bagor, Bogor.
Ogundari K, Ojo.SO.2008. An examination of tecnical, economic, and allocative efficiency of small farms : the case studyof cassava farmers in Osun State of Nigeria. Bulgarian Journal of Agricultural Science.13 (2008):185-195.

Prayoga, A. 2010. Produktivitas dan Efisiensi Teknis Usahatani Padi Organik Lahan Sawah. JAE, 28(1): 1-16.

[PUSLITBANG] Pusat Penelitian dan Pengembangan Tanaman Pangan. Peningkatan Produksi Padi Menuju 2020.

http://www.puslittan.bogor.net/

diakses pada tanggal 12 April 2015.

Sumaryanto, S., Siregar, M., dan Wahidah, W. 2003. Determinan Efisiensi Teknis Usahatani Padi di Lahan Sawah Irigasi. Jurnal Agro Ekonomi,21(1) :72 -96.

Tien. 2011. Analisis efisiensi teknis usahatani padi sawah aplikasi pertanian organik. El-Hayah Vol. 1 (4) : 182-190.

Tiedemann $\mathrm{T}$ and Uwe L.2012.Production risk and tecnical efficiency in organic and conventional agriculture-the case of arable farms in Germany. Journal of Agricultural Economics.2012,Vol.64(2):73-96.

Yasin M, Ashfaq, Adil, and Bakhsh.2014.Profit efficiency of organic vs conventional wheat production in rice-wheat zone of Punjab, Pakistan. J. Agric. Res.52(3):431-452. 